dehydration or plasmolysis. Protoplast structure is better preserved during cryopreservation as the rigours of dehydration are circumvented and less wrinkling is apparent in frozen specimens.

Holes or invaginations have been observed at the surface of many of the protoplasts. These do not appear to be interruptions of the membrane and have been observed by other workers (e.g. Burgess et al. 1977). They were not present on protoplasts that were plasmolysed, fixed, then treated with enzymes. The suggestion is advanced that these holes result from enzyme damage caused by the presence of proteases as impurities in the cell wall degrading enzymes.

Protoplast regeneration Protoplasts were cultured on a modification of Moore's medium. The frequency of regeneration was generally low, the greatest percentage occurring with protoplasts isolated from crowded, slow-growing, more juvenile gametophyte cultures prolonged in the antheridial phase (possibly due to APt production from the faster growing individuals; see Näf 1979, for review of antheridiogens). These gametophytes show parallels with the ameristic tumerous gametophytes, the protoplasts of which are capable of regeneration (Partanen et al. 1980). It seems that the regenerative capacity of Pteridium protoplasts is primarily dependent on the physiological condition of the cultures from which they are derived. A build-up of $A_{P_{t}}$ in the medium is therefore thought to be responsible for the change in cell wall composition which seems to occur as prothalli mature, as mentioned above.

Burgess, J., Linstead, P. J. and Fisher, V. E. L. 1977. Studies on higher plant protoplasts by scanning electron microscopy. Micron 8, 113-122.

Huckaby, C. S., Bassel, A. R. and Miller, J. H. 1982. Isolation of rhizoid and prothallial protoplasts from gametophytes of the fern Onoclea sensibilis. Pl. Sci. Lett. 25, 203-208.

Näf, U. 1979. Antheridiogens and antheridial development. In The Experimental Biology of Ferns, ed. Dyer, A. F., pp. 436-470. London: Academic Press.

Partanen, C. R., Power, J. B. and Cocking, E. C. 1980. Isolation and division of protoplasts of Pteridium aquilinum. Pl. Sci. Lett. 17, 333-338.

Wada, M. and Staehelin, L. A. 1981. Freeze-fracture observation on the plasma membrane, the cell wall and the cuticle of growing protonemata of Adiantum capillus-veneris L. Planta 151, 462-468.

\title{
Curl-tip disease and the potential use of Phoma aquilina as an agent of biological control of bracken
}

\author{
M. N. Burge and J. A. Irvine \\ Biology Division, Department of Bioscience and Biotechnology, \\ University of Strathclyde, Glasgow, U.K.
}

Forty-eight sites for curl-tip disease of bracken have so far been discovered in Great Britain. Three common fungal isolates from diseased tissue are Phoma aquilina, Ascochyta pteridis and Septoria sp. The most virulent isolate, as revealed after inoculations via wounds, is $P$. aquilina. Spores of this fungus will cause infection when 
sprayed onto young bracken fronds but only when nutrient $(2 \%$ malt broth) is supplied with the inoculum and the relative humidity of the growth chamber is maintained at $100 \%$. Infection at lower relative humidity can be achieved by applying the inoculum in a mixture of dilute herbicide (ioxynil), a 'sticker' (glycerol), and nutrient ( $2 \%$ malt broth).

A disease of bracken in the U.S.A. is caused by a species of Ascochyta. The pathogenicity of this fungus to bracken in Britain is to be investigated.

The work is supported by a grant from the Agricultural Research Council.

\section{Pteridium aquilinum: weed or resource?}

\section{T. V. Callaghan}

Institute of Terrestrial Ecology, Natural Environmental Research Council, Merlewood Research Station, Grange-over-Sands, Cumbria LA11 6JU, U.K.

and

\section{E. Sheffield}

Department of Botany, University of Manchester, Manchester M13 9PL, U.K.

The Institute of Terrestrial Ecology has completed a survey of plant production in the U.K. and assessed the potential biomass resource. This is equivalent to $33 \%$ of U.K. energy demand. Biomass within the U.K. could therefore save $£ 1$ billion in oil imports by 2,000 A.D. Natural vegetation could be an important source of biofuels, although not all is harvestable (a contribution of $10 \%$ seems realistic). Many types of natural vegetation are extensive and productive but are not utilised; bracken, for example, covers $3,220 \mathrm{~km}^{2}$ of Great Britain and can reach above-ground productivity of $14 \mathrm{t} / \mathrm{ha} / \mathrm{yr}$. Farmers pay $£ 120$ per hectare to get rid of it at present, but, instead of using herbicides, they could be using it as an energy crop. Bracken gives high yields consistently between sites and years, and conventional harvesting equipment can be used for collection in some sites. Autumn harvesting allows retranslocation of nutrients to rhizomes and affects regrowth less than summer harvesting. Densification of autumn harvest yields a high grade fuel, while gasification or anaerobic digestion of summer harvest yield methanol or methane respectively. Densification yields briquettes suitable for domestic consumption (direct burning) and, together with gasification and anaerobic digestion products, could stimulate rural economies. Realistic costings give a price per barrel of oil equivalent (currently approximately $£ 35$ ) of $£ 12.02$ for briquettes, $£ 41.72$ for methanol and $£ 65.36$ for methane. Bracken can therefore be viewed as a valuable resource rather than a weed, and research is about to commence in the area of control of bud dormancy as part of a continuing programme of bracken utilisation.

This work was funded by the U.K. Department of Energy. Continuing research is funded also by the European Commission and at Manchester University by N.E.R.C. 